( С. $\boldsymbol{Є}$. Хаджинова, канд. техн. наук, Інститут папірництва і поліграфії, Лодзинський технічний університет, Лодзь,

Польща, К. І. Золотухіна, канд. техн. наук, доцент, Б. Р. Кушлик, канд. техн. наук, О. І. Кушлик-Дивульська, канд. фіз. -мат. наук, доцент, КПІ ім. Ігоря Сікорського, Київ, Україна

\title{
ВИЯВЛЕННЯ ЗАЛЕЖНОСТЕЙ ЕКСПЕРИМЕНТАЛЬНИХ ДОСЛІДЖЕНЬ КРАЙОВОГО КУТА ЗМОЧУВАННЯ
}

Досліджено взаємодію різних типів задруковуваних матеріалів з рідинами, зміну крайового кута змочування та адгезію рідини до поверхні зразків, показано лінійну залежність зміни крайового кута з часом, опрацьовано дані математичними методами.

\section{Ключові слова: задруковуваний матеріал; крайовий кут змочування; папір; плівка; крапля; метод найменших квадратів; показник пористості; поверхневий об'єм води; кореляція.}

\section{Постановка проблеми}

Стабільність друкарського процесу, отримання якісних відбитків залежать від багатьох чинників, одним з яких $є$ структура задруковуваного матеріалу і його здатність сприймати рідину. Контакт задруковуваного матеріалу з рідиною $€$ неминучим під час виконання багатьох технологічних процесів поліграфічного виробництва. Зволожувальний розчин у офсетному способі контактує з папером у процесі друкування водно-фарбовою емульсією. Фарби для флексографічного способу друку та чорнила для струминного є малов'язкими і потребують задруковуваного матеріалу з особливою морфологією поверхні. Ступінь змочування рідиною поверхні задруковуваного матері- алу визначає вид технологічного процесу та впливає на стабільність кольоровідтворення [1-4].

Вивчення взаємодії задруковуваних матеріалів з рідинами $€$ важливим, оскільки в процесі друкування можуть виникнути проблеми не лише в момент взаємодії складників, а й у процесі проникнення рідини (воднофарбової емульсії, чорнил тощо) у товщу матеріалу. Проведення експериментального дослідження, опрацювання отриманих даних математичними методами з метою перевірки їх достовірності та подальшого дотримання вимог стандартів друкування $€$ актуальним. Зокрема, вивчення динаміки зміни крайових кутів змочування на поверхні 
різних задруковуваних матеріалів дозволяє оцінити їх здатність сприймати водні чорнила тощо.

\section{Мета роботи}

Визначення взаємодії задруковуваних матеріалів з рідинами та вивчення динаміки зміни крайових кутів змочування на поверхні зразків задруковуваних матеріалів з різним покриттям.

\section{Аналіз попередніх досліджень}

Оптимальна товщина і рівномірність нанесення фарбового шару на відбиток $€$ запорукою отримання якісних відбитків. Для досягнення однорідного, рівномірного шару, фарба повинна мати певні реологічні, адгезійні та змочувальні властивості, відповідати морфології поверхні задруковуваного матеріалу тощо.

Повнота заповнення фарбою мікронерівностей поверхні задруковуваного матеріалу при флексографічному друці та зміна його шорсткості в процесі друку вивчена у роботі [5]. Визначення поверхневої енергії плівок, термодинамічної роботи адгезії фарби до їх поверхні наведено в роботі [6].

Формування властивостей паперу залежно від його складу, текстурних характеристик поліграфічних видів паперу і картону, виду задруковуваного матеріалу, наявності захисного покриття та їх впливу на процес перенесення та формування відбитка наведено в роботах [5-12]. У них деталізуються сутність перетворень, що відбуваються у друкарському контакті, а також засоби їх вдосконалення, що відображають вирішення окремих аспектів. Однак недостатньо увиразнено причини, що впливають на формування проблем у процесі взаємодії задруковуваних матеріалів з рідинами та їх перенесенні в товщі паперу.

Зазвичай, для дуже малих крапель (об'єм яких $є$ меншим від 10-4 мл) вплив гравітаційних сил на форму краплі $€$ незначним, тому крапля розглядається як фрагмент сфери. В роботі [13] крайовий кут змочування визначено за допомогою залежності $\operatorname{tg} \frac{\theta}{2}=\frac{2 \mathrm{~h}}{\mathrm{~d}}$, де кут $\theta$ отримано на основі результатів вимірювання висоти $\mathrm{h}$ та діаметру d основи лежачої краплі на твердій поверхні.

У роботі [14] запропоновано методику визначення крайового кута змочування за виміряним тиском у краплі визначеного об'єму, яка формується на поверхні досліджуваного твердого тіла. Одержані результати апроксимовані за допомогою ортогональних поліномів Чебишова типу $\cos \varphi=1-\mathrm{P}_{v} \sum_{\mathrm{i}=1}^{\mathrm{n}} \mathrm{C}_{\mathrm{i}} \mathrm{P}_{\mathrm{v}}^{\mathrm{i}}$, із наведеними значеннями коефіцієнтів поліноміальної залежності різних степенів.

За цією методикою витискують краплю розрахованого об'єму на поверхню твердого тіла і вимірюють надлишковий тиск у краплі (у капілярі, який з'єднує краплю з пристроєм її утворення), за отриманим значенням тиску визначають згідно з отриманими поліномами Чебишова крайовий кут змочування $\varphi$. 
Приведений метрологічний аналіз показав, що наведена методика розрахунку $\cos \theta(\theta-$ крайовий кут змочування, який утворений дотичними до міжфазних поверхонь, які обмежують змочуючу рідину) таким чином не перевищує 0,1\%.

\section{Результати проведених досліджень}

Для експерименту відібрано наступні види задруковуваних матеріалів відомих виробників:

- папір крейдований (матовий та глянцевий), маса: 130-400 г/м²;

- папір офсетний, маса:

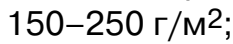

- папір металізований різного відтінку, маса: 280 г/м²;
- плівки (біла та прозора), товщина: 80 мкм.

Експеримент проведено шляхом вимірювання крайового кута змочування з використанням гоніометру PGX «Fibro Systems». Крайовий кут, діаметр контакту краплі з поверхнею, висота краплі піддавалися вимірюванню в п'яти різних зонах кожного зі зразків. Динаміка зміни крайового кута реєструвалася впродовж 60 с. За 60 с отримувалося 10 точок. Для математичного обґрунтування обрано результати вимірювання, отримані впродовж 30 с реєстрації параметрів. Дані вимірювань наведено в таблиці 1.

Таблиця 1

Середні значення крайового кута змочування

\begin{tabular}{|c|c|c|c|c|c|c|}
\hline Тип ЗМ & 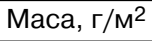 & $t_{0}=0 \mathrm{c}$ & $t_{1}=7,5 \mathrm{c}$ & $t_{2}=15 c$ & $t_{3}=22,5 c$ & $t_{4}=30 c$ \\
\hline \multicolumn{7}{|c|}{ 1. Папір крейдований, глянцевий } \\
\hline № 1 & 130 & 51,13 & 50,17 & 49,60 & 49,27 & 48,43 \\
\hline № 2 & 200 & 52,03 & 51,83 & 50,83 & 50,40 & 49,63 \\
\hline № 3 & 250 & 65,60 & 61,22 & 60,37 & 60,00 & 59,33 \\
\hline № 4 & 300 & 65,50 & 59,53 & 57,40 & 56,83 & 55,97 \\
\hline \multicolumn{7}{|c|}{ 2. Папір крейдований, матовий } \\
\hline № 1 & 130 & 58,97 & 47,40 & 45,73 & 44,07 & 42,40 \\
\hline № 2 & 170 & 94,33 & 84,93 & 84,13 & 83,43 & 81,90 \\
\hline № 3 & 250 & 55,87 & 51,07 & 50,87 & 49,50 & 49,73 \\
\hline № 4 & 350 & 79,63 & 74,57 & 73,90 & 73,43 & 72,93 \\
\hline № 5 & 400 & 74,20 & 58,90 & 58,50 & 59,87 & 57,13 \\
\hline \multicolumn{7}{|c|}{ 3. Папір офсетний } \\
\hline № 1 & 150 & 75,50 & 69,10 & 68,00 & 67,40 & 66,30 \\
\hline № 2 & 170 & 73,37 & 66,83 & 60,83 & 51,40 & 46,33 \\
\hline № 3 & 250 & 71,63 & 65,40 & 53,43 & 33,50 & 24,23 \\
\hline \multicolumn{7}{|c|}{ 4. Папір дизайнерський } \\
\hline № 1 & 280 & 105,33 & 106,93 & 105,80 & 105,33 & 105,20 \\
\hline № 2 & 280 & 80,13 & 80,87 & 81,07 & 80,27 & 79,97 \\
\hline № 3 & 280 & 70,27 & 68,53 & 68,53 & 68,33 & 68 \\
\hline \multicolumn{7}{|c|}{ 5. Плівка } \\
\hline № 1 & - & 69,97 & 71,07 & 70,60 & 70,30 & 70,37 \\
\hline № 2 & - & 65,63 & 67,00 & 67,03 & 66,57 & 66,30 \\
\hline
\end{tabular}


Для паперу крейдованого, глянцевого та матового визначено залежність крайового кута змочування як функцію, лінійну залежність у вигляді у $=$ at + b. Згідно 3 методом найменших квадратів складаємо вираз:

$$
\mathrm{S}(\mathrm{a}, \mathrm{b})=\sum_{\mathrm{i}=1}^{5}\left(\mathrm{y}_{\mathrm{i}}-\left(\mathrm{at}_{\mathrm{i}}+\mathrm{b}\right)\right)^{2} .
$$

Так, для паперу № 1 типу 3 (ма-

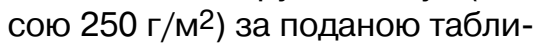
цею значень

\begin{tabular}{|c|c|c|c|c|c|}
\hline $\mathrm{T}$ & 0 & 7,5 & 15 & 22,5 & 30 \\
\hline $\mathrm{y}$ & 65,6 & 61,22 & 60,37 & 60,00 & 59,33 \\
\hline
\end{tabular}

знаходимо коефіцієнти системи рівнянь (із необхідних умов мінімуму функції двох змінних)

$$
\begin{aligned}
& \sum_{\mathrm{i}=1}^{5} \mathrm{y}_{\mathrm{i}} \mathrm{t}_{\mathrm{i}}=4494,6 ; \quad \sum_{\mathrm{i}=1}^{5} \mathrm{t}_{\mathrm{i}}^{2}=1687,5 ; \\
& \sum_{\mathrm{i}=1}^{5} \mathrm{y}_{\mathrm{i}}=306,52 ; \quad \sum_{\mathrm{i}=1}^{5} \mathrm{t}_{\mathrm{i}}=75, \text { тоді, }
\end{aligned}
$$

відповідна система рівнянь

$$
\left\{\begin{array}{l}
1687,5 a+75 b=4494,6 \\
75 a+5 b=306,52
\end{array}\right.
$$

дає значення $\mathrm{a} \approx-0,183$ та $\mathrm{b} \approx$ $\approx 64,06$. Пряма має вигляд:

$$
y=-0,183 t+64,06
$$

Аналогічно отримано лінійні залежності для решти видів паперу, але з використанням вбудованої функції Microsoft Excel ЛИНЕЙН (Известные_значения_; Известные_значения_; Конст; Статистика), яка повертає параметри лінійного наближення за методом найменших квадратів.
Отже, лінійні залежності крайового кута змочування від часу для паперу крейдованого глянцевого для всіх №№ 1-4 мають відповідний запис: 1) y $=-0,084 t+50,98$; 2) $y=-0,08307 t+52,19 ; 3) y=$ $=-0,18347 \mathrm{t}+64,056 ; 4) \mathrm{y}=$ $=-0,29013 t+63,398 ;$ також для паперів крейдованих матових за №№ 1-5: 1) y $=-0,48627 \mathrm{t}+$ $+55,008 ; 2) y=-0,35147 t+91,016$ 3) $y=-0,18467 t+54,168$; 4) $y=$ $=-0,19387 \mathrm{t}+77,8 ; 5) \mathrm{y}=-0,44227 \mathrm{t}+$ $+68,354$.

На рисунку 1 графічно відображено кінетику зміни крайового кута змочування дистильованою водою при дослідженні офсетного паперу різної маси.

Перевіримо припущення стосовно квадратичної залежності, тобто наближення многочленом другого степеня $\mathrm{F}(\mathrm{t})=\mathrm{a}_{0}+\mathrm{a}_{1} \mathrm{t}+$ $+\mathrm{a}_{2} \mathrm{t}^{2}$. Тоді для функції

$$
\begin{aligned}
& S\left(a_{0}, a_{1}, a_{2}\right)= \\
& =\sum_{i=1}^{5}\left(y_{i}-\left(a_{2} t_{i}^{2}+a_{1} t_{i}+a_{0}\right)\right)^{2}
\end{aligned}
$$

система лінійних алгебраїчних рівнянь в загальному випадку для визначення чисел $\mathrm{a}_{0}, \mathrm{a}_{1}, \mathrm{a}_{2}$ має вигляд:

$$
\left\{\begin{array}{l}
5 \mathrm{a}_{0}+\mathrm{a}_{1} \sum_{\mathrm{i}=1}^{5} \mathrm{t}_{\mathrm{i}}+\mathrm{a}_{2} \sum_{\mathrm{i}=1}^{5} \mathrm{t}_{\mathrm{i}}^{2}=\mathrm{b} \sum_{\mathrm{i}=1}^{5} \mathrm{y}_{\mathrm{i}}, \\
\mathrm{a}_{0} \sum_{\mathrm{i}=1}^{5} \mathrm{t}_{\mathrm{i}}+\mathrm{a}_{1} \sum_{\mathrm{i}=1}^{5} \mathrm{t}_{\mathrm{i}}^{2}+\mathrm{a}_{2} \sum_{\mathrm{i}=1}^{5} \mathrm{t}_{\mathrm{i}}^{3}=\sum_{\mathrm{i}=1}^{5} \mathrm{t}_{\mathrm{i}} \mathrm{y}_{\mathrm{i}}, \\
\mathrm{a}_{0} \sum_{\mathrm{i}=1}^{5} \mathrm{t}_{\mathrm{i}}^{2}+\mathrm{a}_{1} \sum_{\mathrm{i}=1}^{5} \mathrm{t}_{\mathrm{i}}^{3}+\mathrm{a}_{2} \sum_{\mathrm{i}=1}^{5} \mathrm{t}_{\mathrm{i}}^{4}=\sum_{\mathrm{i}=1}^{5} \mathrm{t}_{\mathrm{i}}^{2} \mathrm{y}_{\mathrm{i}} .
\end{array}\right.
$$

Для офсетного паперу № 2 типу 3 (масою 170 г/м²) за поданою таблицею значень система рівнянь набуває вигляду: 
$5 \mathrm{a}_{0}+75 \mathrm{a}_{1}+1687,5 \mathrm{a}_{2}=298,76$;

$\left\{75 a_{0}+1687,5 a_{1}+42187,5 a_{3}=3960,075 ;\right.$

$1687,5 \mathrm{a}_{0}+42187,5 \mathrm{a}_{1}+1120078 \mathrm{a}_{3}=85164,19 ;$

з якої отримано $F(t)=-0,00062 t^{2}-$

- 0,90813t + 73,584, причому близьким до нуля $€$ коефіцієнт $\mathrm{a}_{0}=-0,00062$. Визначимо середню похибку апроксимації за відомою формулою:

$$
E=\frac{100 \%}{n} \sum_{i=1}^{n}\left|\frac{F\left(t_{i}\right)-y_{i}}{F\left(t_{i}\right)}\right| .
$$

Провівши обчислення, маємо $\mathrm{E}=6,062 \%$, тобто помилка складає приблизно $6 \%$, причому коефіцієнт кореляції (детермінації) в цьому випадку є близьким до одиниці: $\mathrm{R}^{2}=0,993$.

Дослідження того ж типу паперу за лінійною залежністю приводить до рівняння прямої вигляду $y=-0,9268 t+73,654$ з помилкою, меншою, ніжЕ=1,216\%, R2 = 0,994.
Для інших типів паперу, в тому числі і плівок за даними експериментальних вимірювань, спостерігається за виглядом графіків лінійна залежність від часу, причому з дуже малим коефіцієнтом а прямої у = at + b, прямі майже горизонтальні. Опрацювання даних привело до таких рівнянь прямих: а) для дизайнерського паперу №№ 1-3: 1) y = $=-0,0248 \mathrm{t}+106,09 ; 2) \mathrm{y}=-0,01227 \mathrm{t}+$ $+80,646$; 3) $y=-0,0632 t+69,68$; б) для плівок за №№ 1-2: a) y = $=-0,0004 \mathrm{t}+70,456$; 2) $\mathrm{y}=$ $=-0,012133 t+66,324$.

Якщо розглянути кінетику зміни крайового кута змочування на різних паперах з точки зору прискорення чи стабілізації зміни протягом часу, то можна помітити цікаві залежності. За перший часовий інтервал на папері типу матового та глянцевого відбувається інтенсивна зміна крайового кута змочування, однак на

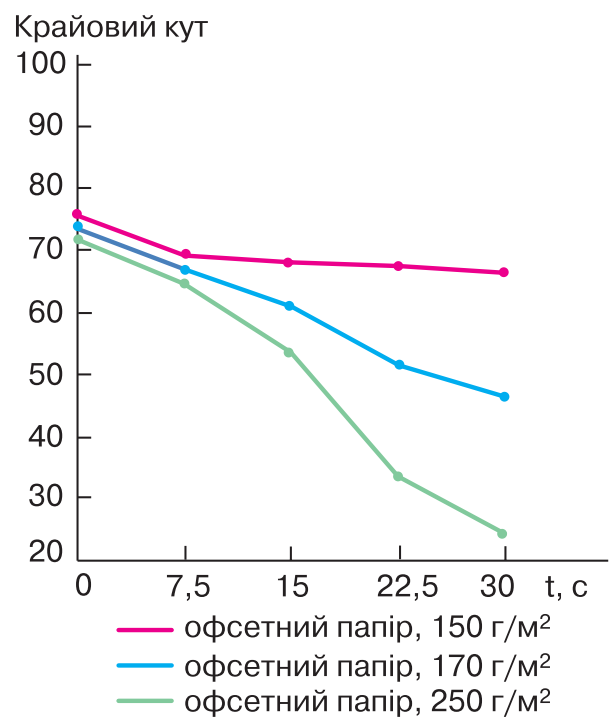

Рис. 1. Кінетика зміни крайового кута змочування дистильованою водою під час дослідження офсетного паперу 
часових проміжках від другого до четвертого прискорення зміни крайового кута стабілізується і відбувається за характеристикою близькою до лінійної.

На противагу крейдованому паперу типу матового та глянцевого, офсетному паперу притаманна інша характеристика. На першому проміжку часу прискорення зміни крайового кута $€$ таким самим, як і для матового та глянцевого, але на наступних відбувається збільшення прискорення зміни крайового кута змочування. Причому, характерно це лише для офсетного паперу більшої маси (170 та 250 г/м²), офсетний папір масою 150 г/м² має схожу характеристику із глянцевим чи матовим крейдованим папером. Пояснити це явище можна тим, що офсетний папір більшої маси має більшу розвиненість капілярів за рахунок своєї товщини, відповідно більш розвиненими у ньому будуть осмотичні явища.

Щодо плівок, то динаміки прискорення зміни крайового кута змочування спостерігатись не буде, що підтверджується їх структурою, відсутністю внутрішньої пористої структури та неможливістю зафіксувати всотування розчинника у матеріал.

Для визначення динаміки проникнення води у структуру паперу застосовано аналізатор динамічного всотування Emtec PEA.C 02.

Результати вимірювання динаміки всотування впродовж перших 20 с, наведені на рис. 2, засвідчують, що плівка є стабільно стійкою до всотування рідини та не придатна до задруковування рідкими чорнилами без попередньої обробки. Дизайнерський папір також має невсотуваль-

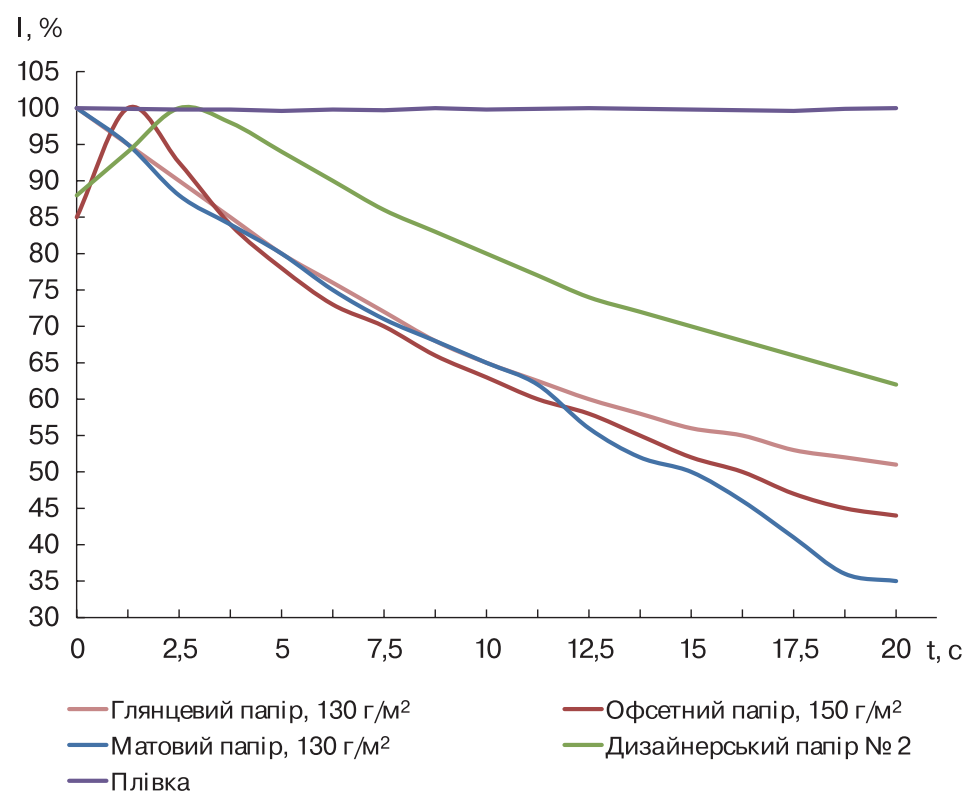

Рис. 2. Динаміка проникнення води в структуру паперу 
ну структуру через металізовані частинки у його складі, що також може призвести до проблем при друкуванні струминним способом.

Дизайнерський папір створює найбільший опір проникненню води (найбільший час 2,36-4,88). Саме цим можна пояснити погане закріплення чорнила на відбитку при використанні струминного способу. Папір офсетний має $\mathrm{T}_{\max }=0,19-2,28$ (рис. 2). Авідразу після контакту крейдованих паперів з рідиною наступає їх максимальне просочування, що підтверджується нулевою фазою зволоження $(\mathrm{W}=0)$.
Це підтверджується проведеними математичними дослідженнями з отриманими рівняннями залежності крайового кута від часу знаходження краплі рідини на поверхні матеріалу, а саме: малий коефіцієнт k, $\mathrm{k}<0,1$ у рівнянні типу $\mathrm{y}=\mathrm{kt}+\mathrm{b}$ характеризується отриманням прямої, близької до горизонтальної.

Найважливіші властивості задруковуваних матеріалів, що перевіряються перед друком та результати вимірювань з РЕА та WSD наведені у таблиці 2. Густина чорнила для струминного друку знаходиться у достатній

Таблиця 2

Результати вимірювання основних показників задруковуваних матеріалів

\begin{tabular}{|c|c|c|c|c|}
\hline Тип 3М & Maca, $г / \mathrm{M}^{2}$ & $\begin{array}{c}\text { Змочування } \\
\text { поверхні паперу, } \\
\mathrm{T}_{95}, \mathrm{~s}\end{array}$ & $\begin{array}{l}\text { Поверхневий } \\
\text { об'єм води, W }\end{array}$ & $\mathrm{T}_{\text {max }}, \mathrm{s}$ \\
\hline \multicolumn{5}{|c|}{ 1. Папір крейдований глянцевий } \\
\hline № 1 & 130 & 1,43 & 0,00 & 0,08 \\
\hline № 2 & 200 & 1,18 & 0,00 & 0,08 \\
\hline № 3 & 250 & 1,55 & 0,00 & 0,08 \\
\hline № 4 & 300 & 3,56 & 0,00 & 0,08 \\
\hline \multicolumn{5}{|c|}{ 2. Папір крейдований, матовий } \\
\hline № 1 & 130 & 1,43 & 0,00 & 0,08 \\
\hline № 2 & 170 & 1,18 & 0,00 & 0,08 \\
\hline № 3 & 250 & 1,77 & 0,00 & 0,08 \\
\hline № 4 & 350 & 3,82 & 0,00 & 0,08 \\
\hline № 5 & 400 & 3,61 & 0,00 & 0,08 \\
\hline \multicolumn{5}{|c|}{ 3. Папір офсетний } \\
\hline № 1 & 150 & 0,99 & 0,16 & 2,28 \\
\hline № 2 & 170 & 0,58 & 0,03 & 0,19 \\
\hline № 3 & 250 & 0,66 & 0,04 & 0,19 \\
\hline \multicolumn{5}{|c|}{ 4. Папір дизайнерський } \\
\hline № 1 & 280 & 1,06 & 0,32 & 2,36 \\
\hline № 2 & 280 & 4,69 & 6,13 & 3,01 \\
\hline № 3 & 280 & 11,37 & 21,4 & 4,88 \\
\hline
\end{tabular}


кореляції з комбінацією вимірювань: визначено показник пористості за точкою (T95), (Tmax) та об'єм поверхні паперу (W). Вплив задруковуваного матеріалу на колірні характеристики відбитка буде мінімальним. Однак різниця у всотувальній здатності може призвести спричинити спотворення і відмінності кольору на різних типах матеріалів.

Як видно з таблиці 2 за показником Т95 низьку проклейку в масі та найбільшу пористість має офсетний папір, який можна вважати найбільш придатним для задруковування струминним способом з усіх досліджуваних. Тонкий крейдований папір (до 250 г/м²) також можна використовувати для задруковування струминним способом для отримання нормованих колірних показників. Усі інші зразки мають низькі показники зволоження рідинами та є проблемними при задруковуванні струминним способом.
Висунуті гіпотези перевірено на відповідність математикостатистичним твердженням достовірності. Розраховано величини кореляції та встановлено кореляційні зв'язки.

Досліджено залежність найбільшого опору проникнення води $\mathrm{T}_{\max }$ від показника пористості по точці (Т95) і поверхневого об'єму води W. Для обраних типів паперу: три типи офсетного та три типи дизайнерського (за номерами 1, 2 та 3), для математичного опрацювання їх позначено, як Z, X та Y, відповідно. 3 математичної точки зору, за умовою поставленої задачі, потрібно для об'єкту, що характеризується трьома ознаками $X, Y$ та Z $(k=3)$, розрахувати $[15,16]$ множинний коефіцієнт кореляції $\mathrm{R}_{\mathrm{z}}$ і частинні коефіцієнти кореляції $R_{X Z}$ та Ryz на основі 6 взаємопов'язаних трійок вибіркових даних

Таблиця 3

Розрахункова таблиця

\begin{tabular}{|c|c|c|c|c|c|c|c|}
\hline & & & & & & & $\bar{\Sigma}$ \\
\hline$x_{i}$ & 0,99 & 0,58 & 0,66 & 1,06 & 4,69 & 11,37 & 19,35 \\
\hline$y_{i}$ & 0,16 & 0,03 & 0,04 & 0,32 & 6,13 & 21,4 & 28,08 \\
\hline$z_{i}$ & 2,28 & 0,19 & 0,19 & 2,36 & 3,01 & 4,88 & 12,91 \\
\hline$x_{i}^{2}$ & 0,9801 & 0,3364 & 0,4356 & 1,1236 & 21,9961 & 129,2769 & 154,1487 \\
\hline$y_{i}^{2}$ & 0,0256 & 0,0009 & 0,0016 & 0,1024 & 37,5769 & 457,96 & 495,6674 \\
\hline$z_{i}^{2}$ & 5,1984 & 0,0361 & 0,0361 & 5,5696 & 9,0601 & 23,8144 & 43,7174 \\
\hline $\mathrm{x}_{\mathrm{i}} \mathrm{y}_{\mathrm{i}}$ & 0,1584 & 0,0174 & 0,0264 & 0,3392 & 28,7497 & 243,318 & 272,6091 \\
\hline $\mathrm{x}_{\mathrm{i}} \mathrm{z}_{\mathrm{i}}$ & 2,2572 & 0,1102 & 0,1254 & 2,5016 & 14,1169 & 55,4856 & 74,5969 \\
\hline $\mathrm{y}_{\mathrm{i}} \mathrm{z}_{\mathrm{i}}$ & 0,3648 & 0,0057 & 0,0076 & 0,7552 & 18,4513 & 104,432 & 124,0166 \\
\hline
\end{tabular}


$\left(x_{i}, y_{i}, z_{i}\right), i=\overline{1, n}, n=6$. Розрахун-

ки для зручності оформимо у вигляді таблиці (табл. 3).

Тоді за відомою [16] формулою:

$$
\begin{aligned}
& R_{z}=R_{3}=\sqrt{1-\frac{|A|}{A_{33}}}= \\
& =\sqrt{1-\frac{0,0156}{0,0083}} \approx 0,9008 .
\end{aligned}
$$

Значення множинного коефіцієнта кореляції $\mathrm{R}_{\mathrm{z}}$ показує, що величина Z сильно пов'язана з X та Y.

Перевірка статистичної значущості множинного коефіціента кореляції $\mathrm{R}_{\mathrm{z}}$, обчислення t-статистики за формулою

$$
\begin{aligned}
& t=\frac{R^{2}(n-k)}{\left(1-R^{2}\right)(k-1)}= \\
& =\frac{0,9008^{2}(6-3)}{\left(1-0,9008^{2}\right)(3-1)} \approx \\
& \approx 6,45
\end{aligned}
$$

та порівняння з критичним значенням $F_{\text {крит. }} F_{\text {крит }}$ - табличне значення розподілу Фішера (за додатком-таблицею значень), яке також можна знайти за допомогою вбудованої статистичної функції Excel FРАСПОБР ( $\alpha$; $\left.\mathrm{I}_{1} ; \mathrm{I}_{2}\right)$, де $\mathrm{F}_{\text {крит }}=$ FРАСПОБР
$(0,085 ; 2 ; 3)=6,259$ приводить до висновку: оскільки $t>F_{\text {крит, }}$ то нульова гіпотеза про відсутність кореляції відхиляється, множинний коефіцієнт кореляції $\mathrm{R}_{\mathrm{z}} \in$ статистично значимим на обраному рівні значущості (тенденція достовірного зв'язку).

Значення частинних коефіцієнтів кореляції $\mathrm{R}_{X Z}=\mathrm{R}_{13} \approx 0,615$ та $R_{Y Z}=R_{23} \approx-0,52$ показують, що величина Z пов'язана з величиною $\mathrm{X}$ сильніше, ніж з величиною $\mathrm{Y}$.

\section{Висновки}

1. Для отримання відбитків струминним способом можна використовувати крейдований та офсетний папір, що підтверджено результатами проведених досліджень. Застосування дизайнерського паперу та плівок може спричинити ускладнення процесу закріплення чорнила на відбитку та отримання неякісної продукції. Встановлено лінійну залежність крайового кута змочування від часу.

2. Показник пористості за точкою (Т95) і поверхневий об'єм води впливають на найбільший опір проникнення води $\mathrm{T}_{\max }$. При цьому змочування поверхні паперу має найбільший вплив на досліджуваний показник. Всі сили зв'язку, t-статистики, є статистично значимими при відповідному виборі рівня значущості.

\section{Список використаної літератури}

1. Кушлик Б. Р. Стабілізація друкування малотиражної продукції офсетним друком: монографія / Б. Р. Кушлик, О. І. Кушлик-Дивульська; за заг. ред. О. М. Величко. Київ: КПІ ім. Ігоря Сікорського, Вид-во «Політехніка», 2017. 162 c.

2. Khadzhynova S. Sposoby drukowania cyfrowego / Svitlana Khadzhynova, Stefan Jakucewicz: Monografie. Łódź: Wydawnictwo Politechniki Łódzkiej, 2016. 242. ISBN 97883-7283-754-7. 
3. Гавенко С. Маркировка: технология, оборудование, материалы: моногр. / С. Гавенко, С. Хаджинова. Львов; Лодзь: Лига-Пресс, 2015. 207 с.

4. Величко О. М. Опрацювання інформаційного потоку взаємодією елементів друкарського контакту / Олена Величко [Текст]: Монографія. К.: ВПЦ «Київський університет», 2005. 264 с.

5. Могинов Р. Г. Экспериментальная проверка влияния шероховатости запечатываемого материала на равномерность оттиска / Р. Г. Могинов, Р. М. Амосов, О. Ю. Затула // Известия высших учебных заведений. Проблемы полиграфии и издательского дела [Текст]: науч.-техн. журн. / М-во образования РФ, Моск. гос. ун-т печати. М.: Изд-во МГУП, 2011. № 4. С. 44-52.

6. Коротка В. О. Дослідження адгезійних властивостей оксо-біорозкладальних плівок при отриманні відбитків трафаретного друку / В. О. Коротка, Р. С. Зацерковна // Квалілогія книги. 2014. № 1(25). С. 28-32.

7. Варепо Л. Г. Моделирование переноса краски в печатной системе между офсетным и печатным цилиндрами печатного аппарата: монография / Л. Г. Варепо, А. В. Паничкин, В. И. Бобров. М.: МГУП, 2013. 188 с.

8. Чиликина Г. С. Текстурные характеристики полиграфических видов бумаги и картона. Дисс. канд. техн. наук. М.: МГУП. 2008. 200 с.

9. Гілета І. В. Модель факторів впливу на процес проектування тактильної продукції / І. В. Гілета, М. М. Гавенко, В.М.Сеньківський // Поліграфія і видавнича справа. 2017. № 1(73). С. 87-96.

10. Leks-Stępień J., Khadzhynova S. Effect of wetting solution components on the rate of penetration into offset paper (Wpływ składników roztworu nawilżającego na szybkość wnikania w strukturę papieru offsetowego) // Przegląd Papierniczy, Vol. 61, No 6 (2005), pp. 337-340.

11. Kryczka M., Khadzhynova S., Skowroński J. Influence of paper properties on digital prints quality. Part 1. (Wpływ właściwości papieru na jakość druków cyfrowych. Część 1) // Przegląd Papierniczy, Vol. 67, No 8 (2011), pp. 489-492.

12. Kryczka M., Khadzhynova S., Skowroński J. Influence of paper properties on digital prints quality. Part 1. (Wpływ właściwości papieru na jakość druków cyfrowych. Część 1) // Przegląd Papierniczy, Vol. 67, No. 10 (2011), pp. 611-615.

13. Зимон А. Д. Адгезия жидкости и смачивание. М.: Химия. 1974. 416 с.

14. Боднар Р. Т. Визначення крайового кута змочування за виміряним тиском в краплі / Р. Т. Боднар, І. С. Кісіль // Методи та прилади контролю якості. 2000. № 5. С. 100-103. [Електронний ресурс]. Режим доступу: http://elar.nung.edu.ua/handle/123456789/487.

15. Кушлик-Дивульська О. І. Методичні вказівки до виконання лабораторних робіт (комп'ютерного практикуму) з дисципліни «Теорія ймовірностей і математична статистика» для студентів напряму підготовки 6.030601 «Менеджмент» студентів Видавничо-поліграфічного інституту [Електронний ресурс]: НТУу «КПІ»; уклад.: О. І. Кушлик-Дивульська, Б. Р. Кушлик. Електронні текстові дані (1 файл: 4,60 Мбайт). Київ: НТУУ «КПІ», 2016. 205 с. Назва з екрана. Доступ: http://ela.kpi.ua/handle/123456789/17693.

16. Кушлик-Дивульська О. І. Теорія ймовірностей та математична статистика: навч. посіб. / О. І. Кушлик-Дивульська, Н. В. Поліщук, Б. П. Орел, П. І. Штабалюк. К.: НТУУ «КПІ», 2014. 212 с. Бібліогр.: с. 205.

\section{References}

1. Kushlyk, B. R. \& Kushlyk-Dyvulska, O. I. (2017). Stabilizatsiia drukuvannia malotyrazhnoi produktsii ofsetnym drukom. Kyiv: KPI im. Ihoria Sikorskoho, Vyd-vo 'Politekhnika', 162 p. [in Ukrainian]. 
2. Khadzhynova, S. \& Jakucewicz, S. (2016). Sposoby drukowania cyfrowego. Łódź: Wydawnictwo Politechniki Łódzkiej, 242 p. [in Polish].

3. Gavenko, S. \& Khadzhinova, S. (2015). Markirovka: tekhnologiya, oborudovanie, materialy. L'vov; Lodz': Liga-Press, 207 p. [in Russian].

4. Velychko, O. M. (2005). Opratsiuvannia informatsiinoho potoku vzaiemodiieiu elementiv drukarskoho kontaktu. Kyiv: VPTs 'Kyivskyi universytet', 264 p. [in Ukrainian].

5. Moginov, R. G. \& Amosov, R. M. \& Zatula, O. Yu. (2011). Eksperimental'naya proverka vliyaniya sherokhovatosti zapechatyvaemogo materiala na ravnomernost' ottiska. Journal of Izvestiya vysshikh uchebnykh zavedeniy. Problemy poligrafii i izdatel'skogo dela, 4, 44-52 [in Russian].

6. Korotka, V. O. \& Zatserkovna, R. S. (2014). Doslidzhennia adheziinykh vlastyvostei okso-biorozkladalnykh plivok pry otrymanni vidbytkiv trafaretnoho druku. Journal of Kvalilohiia knyhy, 1(25), 28-32 [in Ukrainian].

7. Varepo, L. G. \& Panichkin, A. V. \& Bobrov, V. I. (2013). Modelirovanie perenosa kraski v pechatnoy sisteme mezhdu ofsetnym i pechatnym tsilindrami pechatnogo apparata. Moscow: MGUP, 188 p. [in Russian].

8. Chilikina, G. S. (2008). Teksturnye kharakteristiki poligraficheskikh vidov bumagi i kartona. Moscow: MGUP, 200 p. [in Russian].

9. Hileta, I. V. \& Havenko, M. M. \& Senkivskyi, V. M. (2017). Model faktoriv vplyvu na protses proektuvannia taktylnoi produktsii. Journal of Polihrafiia $i$ vydavnycha sprava, 1(73), 87-96 [in Ukrainian].

10. Leks-Stępień, J. \& Khadzhynova, S. (2005). Effect of wetting solution components on the rate of penetration into offset paper (Wpływ składników roztworu nawilżającego na szybkość wnikania w strukturę papieru offsetowego). Journal of Przegląd Papierniczy, Vol. 61, No 6, 337-340 [in Polish].

11. Kryczka, M. \& Khadzhynova, S. \& Skowroński, J. (2011). Influence of paper properties on digital prints quality. Part 1. (Wpływ właściwości papieru na jakość druków cyfrowych. Część 1). Journal of Przegląd Papierniczy, Vol. 67, No 8, 489-492 [in Polish].

12. Kryczka, M. \& Khadzhynova, S. \& Skowroński, J. (2011). Impact of paper properties on Quality of digital prints. Part 2. (Wpływ właściwości papieru na jakość druków cyfrowych. Część 2). Journal of Przegląd Papierniczy, Vol. 67, No. 10, 611-615 [in Polish].

13. Zimon, A. D. (1974). Adgeziya zhidkosti i smachivanie. Moscow: Khimiya, 416 p. [in Russian].

14. Bodnar, R. T. \& Kisil, I. S. (2000). Vyznachennia kraiovoho kuta zmochuvannia za vymirianym tyskom v krapli. Journal of Metody ta prylady kontroliu yakosti, 5, 100-103. Retrieved from http://elar.nung.edu.ua/handle/ $123456789 / 487$ [in Ukrainian].

15. Kushlyk-Dyvulska, O. I. \& Kushlyk, B. R. (2016). Metodychni vkazivky do vykonannia laboratornykh robit (komp'iuternoho praktykumu) z dystsypliny 'Teoriia ymovirnostei i matematychna statystyka' dlia studentiv napriamu pidhotovky 6.030601 'Menedzhment' studentiv Vydavnycho-polihrafichnoho instytutu. Kyiv: NTUU 'KPI', 205 p. Retrieved from http://ela.kpi.ua/handle/ 123456789/17693 [in Ukrainian].

16. Kushlyk-Dyvulska, O. I. \& Polishchuk, N. V. \& Orel, B. P. \& Shtabaliuk, P. I. (2014). Teoriia ymovirnostei ta matematychna statystyka. Kyiv: NTUU 'KPI', 212 p. [in Ukrainian]. 
Исследовано взаимодействие различных типов запечатываемых материалов с жидкостями, изменение краевого угла смачивания и адгезию жидкости к поверхности образцов. Разработана методология детальных экспериментальных исследований для досконального изучения явлений, возникающих на поверхности запечатываемого материала (нескольких типов бумаг, дизайнерских картонов и пленок) при их смачивании жидкостями. Установлены пределы и временные рамки проведения эксперимента, обосновано отбор материалов для исследования и зафиксированы полученные результаты.

Ключевые слова: запечатываемый материал; краевой угол смачивания; ускорение изменения краевого угла; бумага; пленка; капля; метод наименьших квадратов; показатель пористости; поверхностный объем воды; корреляция.

Various types of printed substrates were researched for their capabilities to interact with liquids, the contact wetting angle was studied as well as the adhesion of the liquid to the substrate's surface. The methodology of detailed experimental research was developed in order to thoroughly study the phenomena occurring on the printed substrate's surface (several paper types, designer's cardboards and papers, films) while being wetted by the liquid. The experimental research frames as well as the timeframes had been set, the experimental material selection was explained, and also the results were fixated.

Keywords: printing material; edge angle of wetting; acceleration of edge angle change; paper; film; drop; least squares method; porosity index; surface water volume; correlation.

Рецензент - В. М. Горбачук, д-р фіз.-мат. наук, доцент, КПІ ім. Ігоря Сікорського 